UDC 636.2:[575.17:577.213.3]

\title{
GENETIC VARIATION DETERMINATION AND INTERBREED DIFFERENTIATION OF TWO UKRAINIAN DAIRY CATTLE BREEDS USING MICROSATELLITE LOCI OF DNA
}

\author{
A. V. Shelyov ${ }^{1}$, K. V. Kopylov ${ }^{1}$, S. S. Kramarenko ${ }^{2}$, O. S. Kramarenko ${ }^{2}$ \\ ${ }^{1}$ Institute of Animal Breeding and Genetics NAAS, \\ 1, Pohrebniaka Str, Chubynske village, Kyiv region, Ukraine, 08321 \\ ${ }^{2}$ Mykolayiv National Agrarian University, \\ 9, Georgiy Gongadze Str., Mykolayiv, Ukraine, 54020 \\ e-mail:shelyov@gmail.com
}

Received on February 25, 2018

\begin{abstract}
Aim. The aim of our work was to investigate the interbreed differentiation of Ukrainian Red-and-Motley and Black-and-White dairy cows based on the results of the analysis of allelic and genotypic polymorphism of DNA microsatellites. Methods. Genotyping of 88 DNA samples of two most numerous dairy cattle breeds in Ukraine - Ukrainian Red-and-Motley and Black-and-White dairy cows - was conducted by 10 loci, recommended by the International Society for Animal Genetics (ISAG). The analysis of allelic and genotypic polymorphism was performed using parametric and non-parametric methods. Results. Informative value of DNA microsatellites as markers of genetic processes, which take place in the populations of domestic animals, was assessed. Conclusions. The investigated breeds demonstrate a reliable level of genetic differentiation with a high level of similarity.
\end{abstract}

Keywords: cattle, DNA-markers, microsatellites, biodiversity, populational genetics.

DOI: $10.15407 /$ agrisp5.01.051

\section{INTRODUCTION}

The estimation of interbreed differentiation of the most numerous cattle breeds in Ukraine is one of the most relevant elements of breeding in domestic animal farming and the preservation of local breeds. One of the most conclusive directions of estimating this characteristic is the analysis of genetic diversity.

DNA microsatellites - highly polymorphic multilocus genetic systems - are highly informative markers of the degree of genetic differentiation for the populations of domestic animals $[1,2,4]$. Almost all the microsatellites are located in qualitative trait loci (QT) or are related to genes, connected to reproduction processes [3].

Microsatellites of DNA have been used for the analysis of genetic diversity of many cattle breeds including Northern breeds [5], breeds of Central [6] and

\footnotetext{
(C) A. V. SHELYOV, K. V. KOPYLOV, S. S. KRAMARENKO, O. S. KRAMARENKO, 2018
}

Eastern Europe [7], breeds of India [8], Africa [9], Korea [10] and Southern-Eastern Asia [4], including those of Indonesia [11].

The most common cattle breeds in Ukraine are Ukrainian Red-and-Motley (URM) and Ukrainian Blackand-White (UBW) breeds. The main aim of this study was to analyze the genetic structure of the mentioned breeds and to determine the degree of their affinity and differentiation.

To this end, an analysis was made of allelic and genotypic polymorphism of microsatellites.

\section{MATERIALS AND METHODS}

The study was conducted using a population $(n=88$ heads) of Ukrainian Red-and-Motley dairy cattle breed (URM; $n=45$ heads) and Ukrainian Black-and-White dairy cattle breed (UBW; $n=43$ heads), kept at the Voronkiv farm in Boryspil district, Kyiv region.

Blood was sampled under sterile conditions from the jugular vein using double-ended needles Venoject 


\section{SHELYOV et al.}

and vacuum tubes and holders Venosafe (Terumo, Belgium) following the standard method in accordance to the manufacturer's recommendations.

DNA isolation from blood samples was conducted using the DNA-sorb-B kit (Amplisense, Russia) according to the manufacturer's recommendations. The microsatellite analysis was performed using 10 loci (Table 1), recommended by the International Society for Animal Genetics (ISAG).

The polymerase chain reaction (PCR) was conducted using an ABI 2720 Thermal Cycler (Applied Biosystems, CA, USA). The reaction mixture for PCR was prepared according to the protocol, recommended by the manufacturer of the test-system (StockMarcs, Cattle Bovine Genotyping Kit (Applied Biosystems, CA, USA). The amplified DNA was separated by the method of capillary gel electrophoresis on an ABI Prism 3130 Genetic Analyzer (Applied Biosystems, CA, USA). Data registration and mapping (genotyping) was performed using programs Run 3130 Data Collection v.3.0 and GeneMapper 3.7 of Applied Biosystems, CA, USA.

The frequencies of alleles and the genotypes were estimated, including one-time (N1), two-times (N2) observed and unique ones (Nunik). The comparison of breeds in terms of frequencies of alleles and genotypes was performed using the criterion $\chi^{2}$ of K. Pearson (by Monte Carlo method for low frequencies) [12] using special software for population-genetic analysis - Ge-
nAIEx [13], BOTTLENECK [14], PopGene [15] and NetEstimator [16].

\section{RESULTS AND DISCUSSION}

The analysis of the allelic diversity of 10 microsatellite loci demonstrated that the highest average number of the allelic variants was found in the population of URM breed -9.5 alleles/locus, whereas the same index for UBW breed was 9.2 alleles/locus. The values of the effective number of alleles were 6.757 and 6.023 alleles/locus, respectively. In our study each breed was characterized by the highest number of alleles in three microsatellite loci out of the 10 investigated ones, namely, URM - in loci TGLA126, BM2113 and SPS115, and URM - in loci INRA23, BMI824 and TGLA227. The differences between breeds did not exceed two alleles. In the remaining loci, the number of allelic variants was the same for the two breeds.

The broadest allelic spectrum was observed for the breed with the highest number of alleles. Loci with a similar number of allelic variants had the same allelic spectrum, except for locus ETH3 that had a wider one. The obtained estimates of the criterion $\chi^{2}$ of K. Pearson allow stating highly reliable $(\mathrm{P}<0.001)$ differences in the distribution of the investigated population by the allelic frequencies in all the investigated loci.

Unique alleles were registered in seven out of ten investigated microsatellite loci, seven $(30 \%)$ for URM breed and five (22\%) - for UBW. A quite similar distribution was found for the number of loci with

Table 1. The number of alleles, including rare ones, calculated using the rarefaction-method $(n=25)$ for 10 microsatellite loci of two cattle breeds, Ukrainian Red-and-Motley (URM) and Ukrainian Black-and-White (UBW)

\begin{tabular}{l|c|c|c|c}
\hline \multirow{2}{*}{ Locus } & \multicolumn{4}{|c}{ Breed } \\
\cline { 2 - 5 } & \multicolumn{2}{|c}{ URM } & Unmber of alleles & inc. rare ones \\
\cline { 2 - 5 } & number of alleles & inc. rare ones & 5.83 & 0.04 \\
TGLA126 & 7.45 & 0.14 & 10.11 & 0.65 \\
TGLA122 & 10.39 & 1.43 & 11.26 & 0.99 \\
INRA23 & 10.50 & 0.20 & 6.92 & 0.45 \\
ETH3 & 6.80 & 1.00 & 7.89 & 0 \\
ETH225 & 7.96 & 0.002 & 9.95 & 0.58 \\
BM1824 & 9.78 & 0.05 & 13.40 & 2.45 \\
TGLA227 & 11.67 & 1.85 & 8.44 & 0.09 \\
BM2113 & 10.82 & 1.45 & 6.99 & 0 \\
ETH10 & 6.98 & 0 & 6.99 & 0.001 \\
SPS115 & 8.55 & 1.84 & $8.78 \pm 0.746$ & $0.53 \pm 0.240$ \\
Mean & $9.09 \pm 0.555$ & $0.80 \pm 0.251$ & & \\
\hline
\end{tabular}



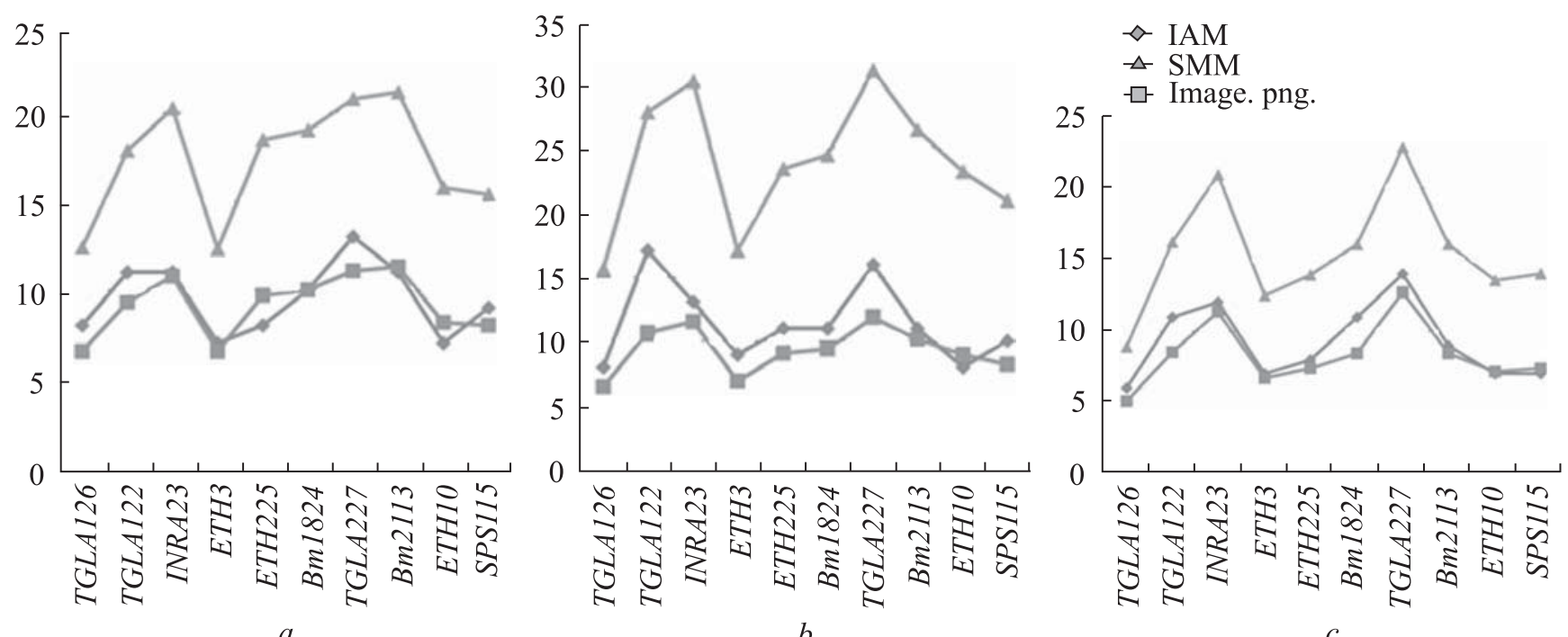

Fig. 1. Actual number of found alleles by DNA microsatellite loci, total $(a)$ and for URM $(b)$ and UBW $(c)$, calculated using different mathematical models

unique alleles: the highest number (five, or $33 \%$ ) was found for URM breed, and the lowest number (four, or $27 \%$ - for UBW. In the populations of URM and UBW, two unique alleles were found in two and one loci (TGLA227, SPS115 and TGLA227), respectively. It should be noted that only in loci TGLA122 and TGLA227 unique alleles were found in both investigated breeds. Unique alleles in loci ETH3, BM2113 and SPS115 were recorded for URM breed, and loci INRA23 and BM1824 - for UBW. In general, the frequency of unique alleles in URM breed (0.049) was almost twice higher than for UBW breed (0.026).

Two main models were used to analyze the character of the distribution of alleles of microsatellite DNA by specific loci - the infinite alleles model (IAM) $[17,18$, 19] and the stepwise mutation model (SMM) [20, 21].

SMM was more adequate for both investigated breeds with the approximation of the level of allelic diversity in all the investigated microsatellite loci without exceptions, compared to IAM model $(\mathrm{P}<0.0001)$. The latter exaggerates the actual values greatly both in general and for each breed, in particular (Fig. 1).

Taking into account our limited number of samples and limited number of loci studies where direct comparison of the obtained results is impossible, we used the rarefaction procedure. The number of alleles (calculated per 25 randomly selected diploid animals) varied greatly both for animals of different breeds and for different loci (Table 1). In general, URM breed had a higher total of alleles and more unique alleles were found than in UBW breed. The highest level of allelic diversity, however, was observed for UBW in locus TGLA227 (13.40 alleles), and the lowest - for the same breed in locus TGLA126 (5.83 alleles). The highest number of unique alleles (2.45) was also found for UBW in locus TGLA227, and the lowest - for the same breed in the locus SPS115 (0.01). The estimates, made using the rarefaction-procedure, prove the absence of unique alleles in both populations for locus ETH1O, and as for UBW - for locus ETH225 as well.

The highest number of genotype variants was found in URM, viz. four microsatellite loci out of ten investigated ones (INRA23, ETH225, TGLA227, BM2113), while for UBW this was found only for three loci TGLA122, ETH3 and BM1824. The number of genotype variants in loci TGLA126, ETH10 and SPS115 was the same for representatives of both breeds.

The analysis of the distribution character of the found genotype frequencies allows stating that URM and UBW breeds demonstrate a high level of similarity by this index (Table 2). There is also a high demonstrated level of polymorphism by the number and character of distribution of the frequencies of the established genotypes, which is proven by the value of the approximating model (the selected exponential function) and the degree of its adequacy and determination coefficient (Fig. 2).

In general, the number of rare genotypes in the representatives of the investigated breeds fluctuated from 11 (in locus TGLA126) to 45 (in locus TGLA227) (Table 2). The tendency of frequency distribution (the same loci were the most and the least polymorphic, etc.) was 


\section{SHELYOV et al.}

found for the total number of genotypes, which were observed only once - from five (in locus TGLA126) to 33 (in locus TGLA227). The lowest number of genotypes, observed only twice each time (four genotypic variants), were found in locus SPS115, and the highest (15) - in locus INRA23. The lowest number of rare genotypes (two variants) determined for the representatives of URM in locus ETH3, and for UBW - in the locus ETH225. The highest number of rare genotypes (10 variants) was found for URM (in locus TGLA122), and as for UBW, this index was eight variants (in locus BM1824). The highest number of genotypes, observed once each time (24 variants), was found for locus TGLA227 in URM, and the lowest (six variants) in the same breed in the loci TGLA126, TGLA122 and ETH3.

The analysis of the frequencies of unique genotypes showed that the lowest number of such genotypes (four genotype variants) was found in the loci TGLA126 and $B M 1824$ in animals of both breeds and in the loci ETH3 and ETH225 - in UBW, and the highest (20 variants) in locus BM2113 in URM. The intrabreed analysis demonstrated that the average number of unique genotypes per locus in URM was 9.0 and fluctuated from four (in loci TGLA126 and BM1824) to 20 (in locus $B M 2113)$. For UBW the average was 8.1 and fluctuated from four (in loci TGLA126, ETH3, ETH225 and $B M 1824$ ) to 17 (in locus TGLA227). It is noteworthy that no differences were found between the breeds in the ratio of three out of ten investigated microsatellite loci, and there was only one genotype variant found in three more.

In general, the analysis of genetic variation in the two Ukrainian breeds of Bos taurus species demonstrated that all the investigated microsatellite loci were characterized by a high number of incongruous genotype variants, for instance, TGLA126 16/116, TGLA126 16/118, TGLA126 ${ }^{116 / 120}$, TGLA126 $118 / 118$, TGLA126 ${ }^{118 / 120}$, etc. Their total number in the animals of this species fluctuated from 21 (in loci TGLA126) to 53 (in locus TGLA227). The highest level of genotype polymorphism was found in loci INRA23 and TGLA227 in URM (32 variants) and UBW (31 variant). Locus ETH3 was found to be the least polymorphic in URM (15 variants), and for UBW it was TGLA126 (16 variants).

According to the nonparametric method of A. Chao, the use of which ensures more accurate comparison of the populations (groups of animals) of different size [22] in general, the distribution for the number of genotypes in the animals of different breeds is incongruous. For instance, in loci TGLA126, INRA23, ETH3, ETH225, TGLA227, ETH10 and SPS115 no reliable difference was found between the breeds, and in locus BM2113 in URM, the potential number of genotypes was much higher than that for the representatives of the other breed.

The parametric rarefaction-procedure was also used to estimate the "possible genotype diversity". The ob-

Table 2. The total number of genotypes, determined, rare and unique genotypes for 10 microsatellite loci of two Ukrainian cattle breeds

\begin{tabular}{|c|c|c|c|c|c|c|c|c|}
\hline \multirow{3}{*}{ Locus } & \multicolumn{8}{|c|}{ Breed } \\
\hline & UR & URM & UR & URM & UR & URM & UR & URM \\
\hline & \multicolumn{2}{|c|}{$\mathrm{N}_{\mathrm{a}}$} & \multicolumn{2}{|c|}{$\mathrm{N}_{1}$} & \multicolumn{2}{|c|}{$\mathrm{N}_{2}$} & \multicolumn{2}{|c|}{$\mathrm{N}_{\text {unik }}$} \\
\hline$T G L A 126$ & 16 & 16 & 6 & 8 & 5 & 3 & 4 & 4 \\
\hline TGLA122 & 21 & 25 & 6 & 14 & 10 & 6 & 11 & 12 \\
\hline INRA 23 & 32 & 31 & 23 & 22 & 7 & 6 & 12 & 12 \\
\hline ETH 3 & 15 & 18 & 6 & 8 & 2 & 5 & 5 & 4 \\
\hline ETH225 & 25 & 19 & 14 & 12 & 6 & 2 & 8 & 4 \\
\hline BM1824 & 24 & 25 & 15 & 13 & 3 & 8 & 4 & 4 \\
\hline TGLA227 & 32 & 31 & 24 & 22 & 5 & 7 & 14 & 17 \\
\hline$B M 2113$ & 31 & 20 & 23 & 8 & 4 & 7 & 20 & 8 \\
\hline ETH10 & 22 & 22 & 10 & 12 & 5 & 4 & 5 & 10 \\
\hline SPS115 & 22 & 22 & 11 & 12 & 3 & 5 & 7 & 6 \\
\hline Mean & 24 & 22.9 & 13.8 & 13.1 & 5 & 5.3 & 9 & 8.1 \\
\hline
\end{tabular}


GENETIC VARIATION DETERMINATION AND INTERBREED DIFFERENTIATION

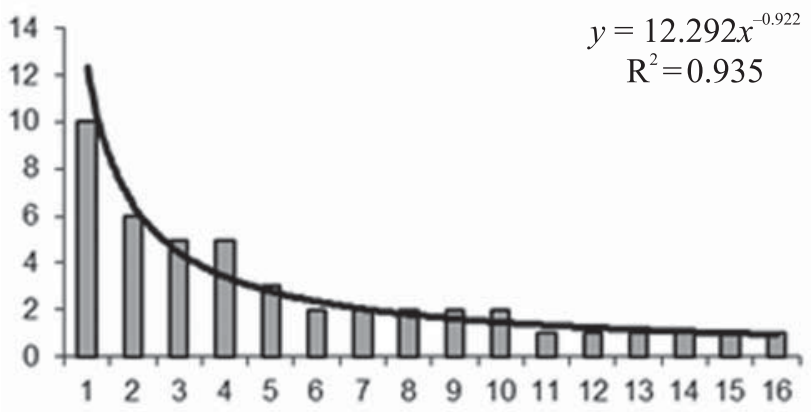
in locus TGLA126 URM
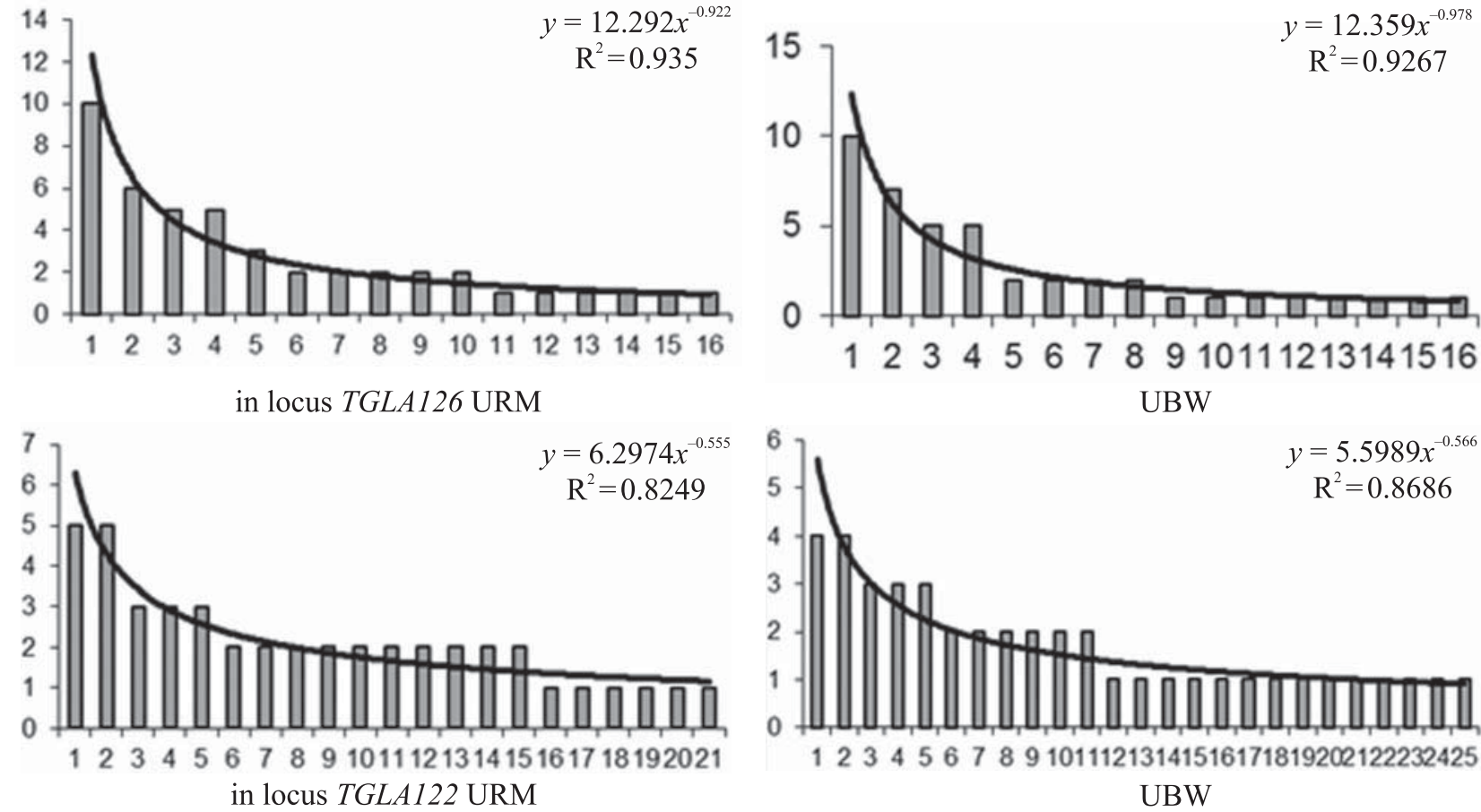

12345678910111213141516 UBW
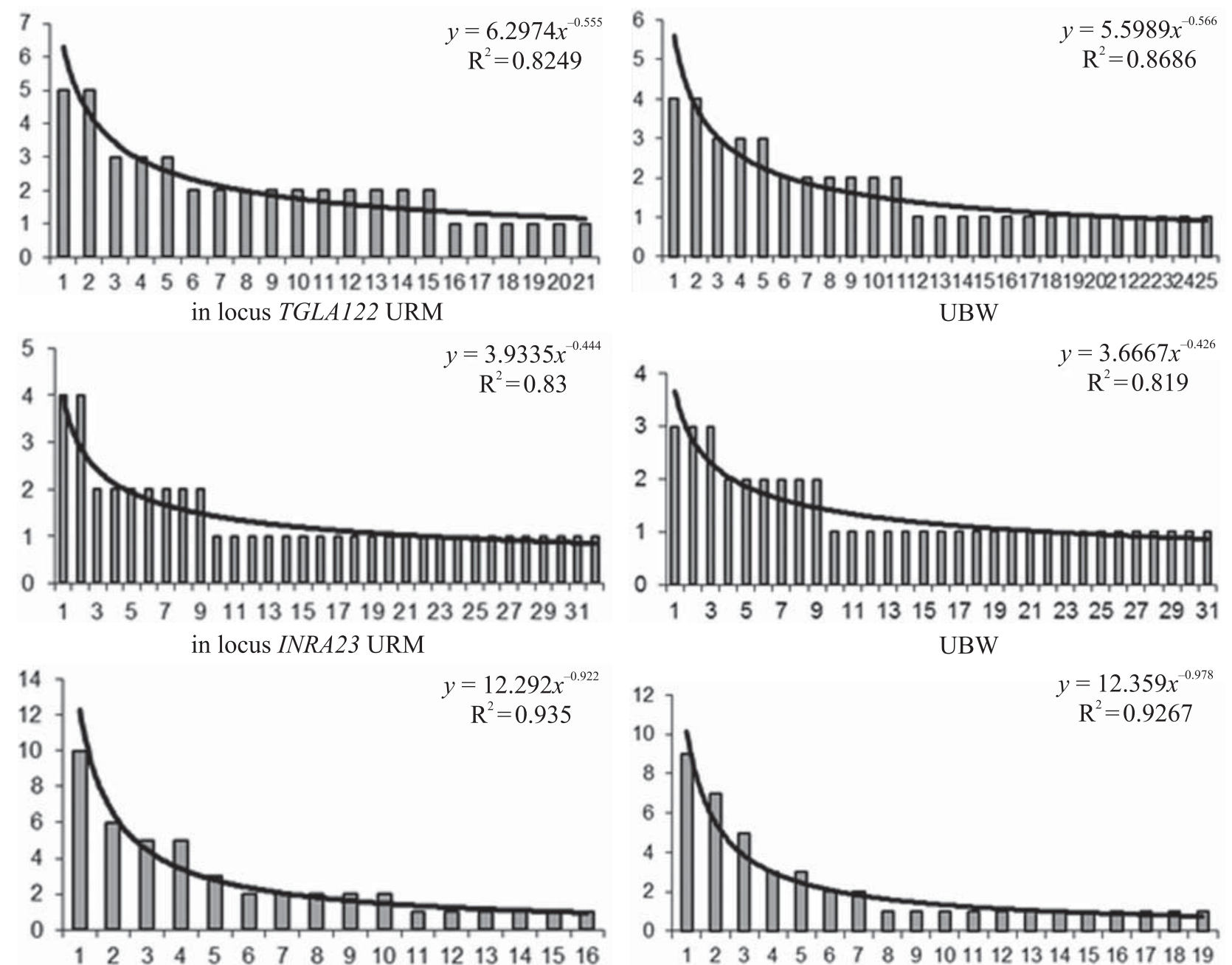
in locus ETH3 URM
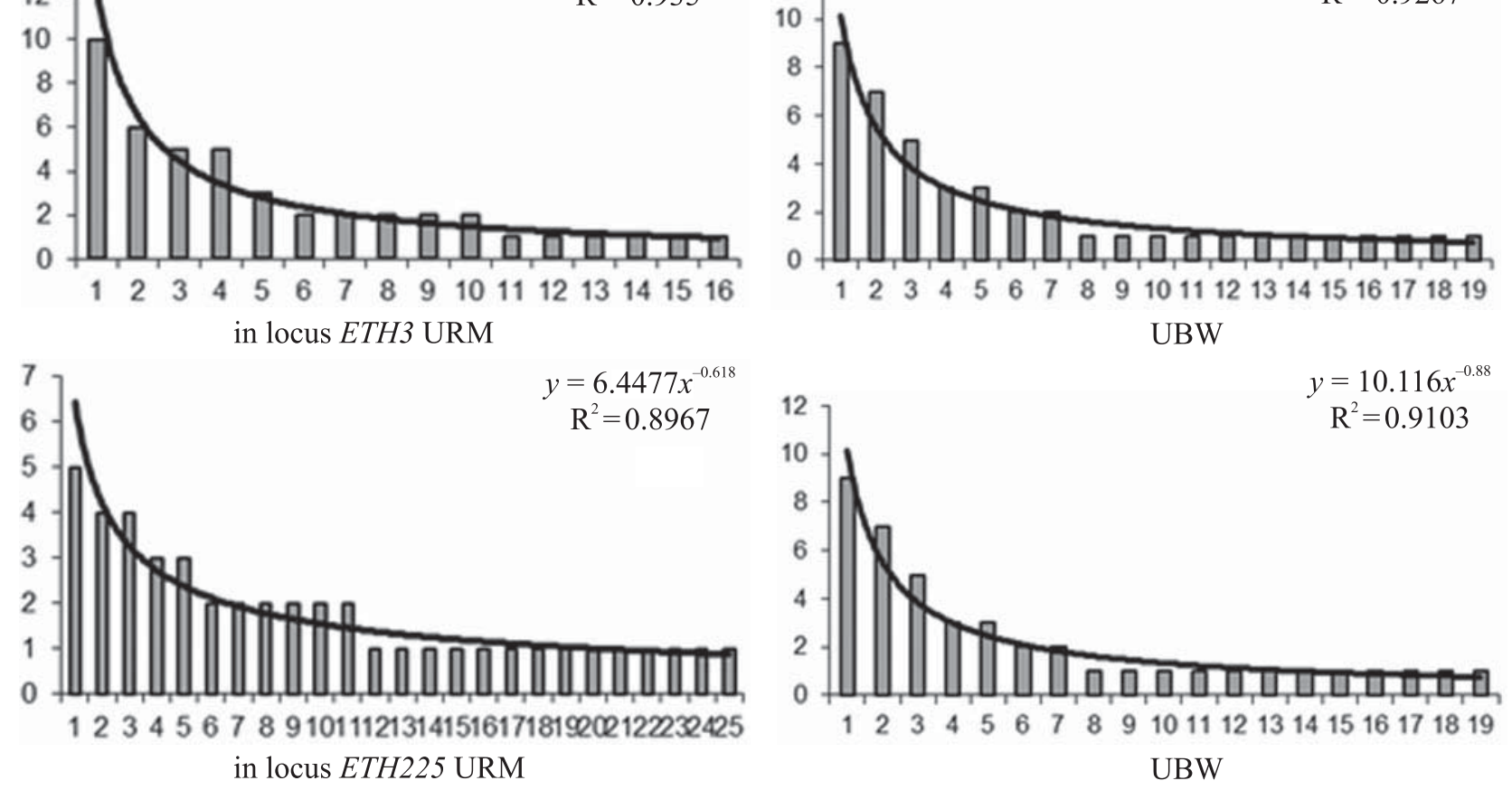
SHELYOV et al.
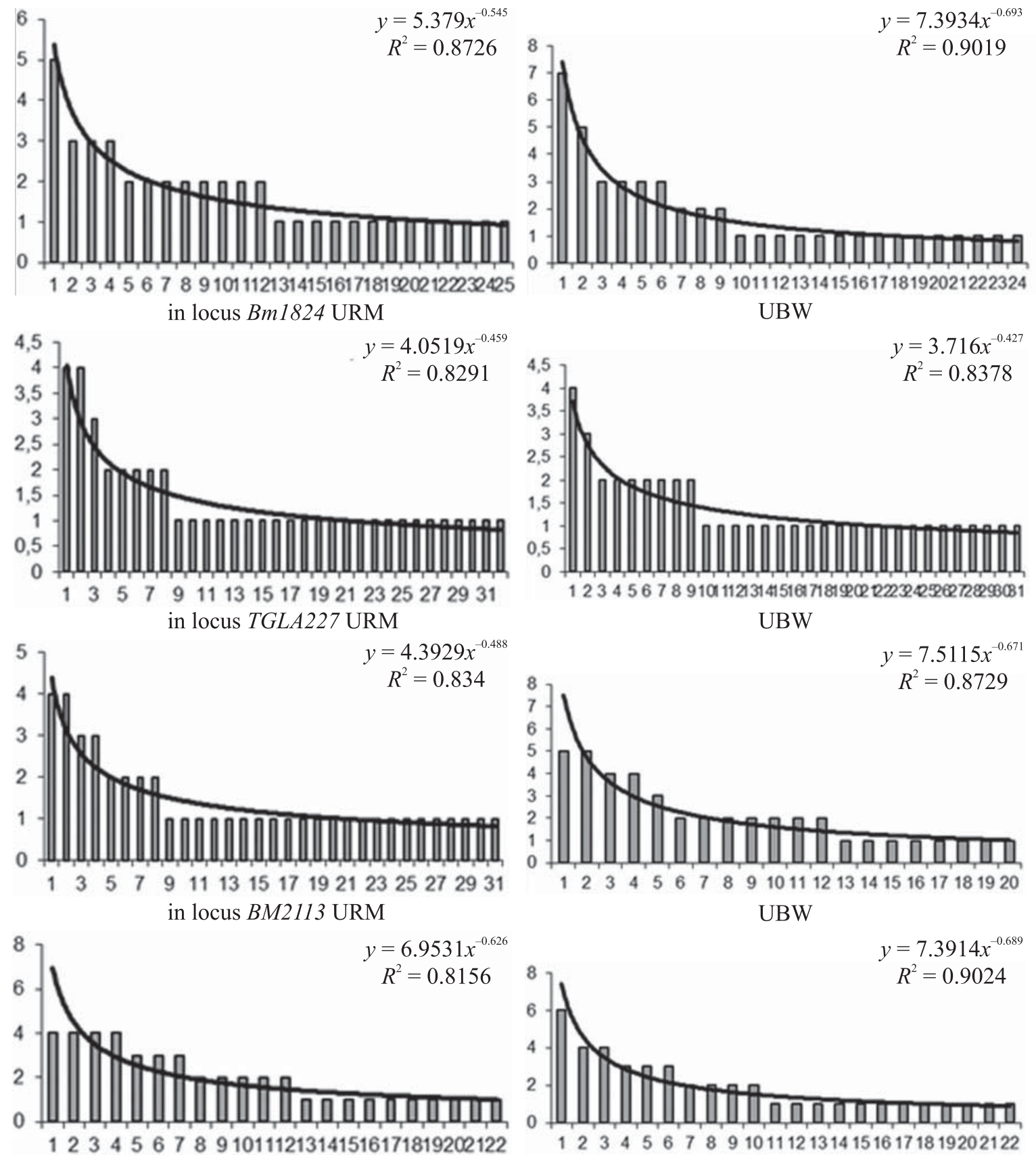

UBW
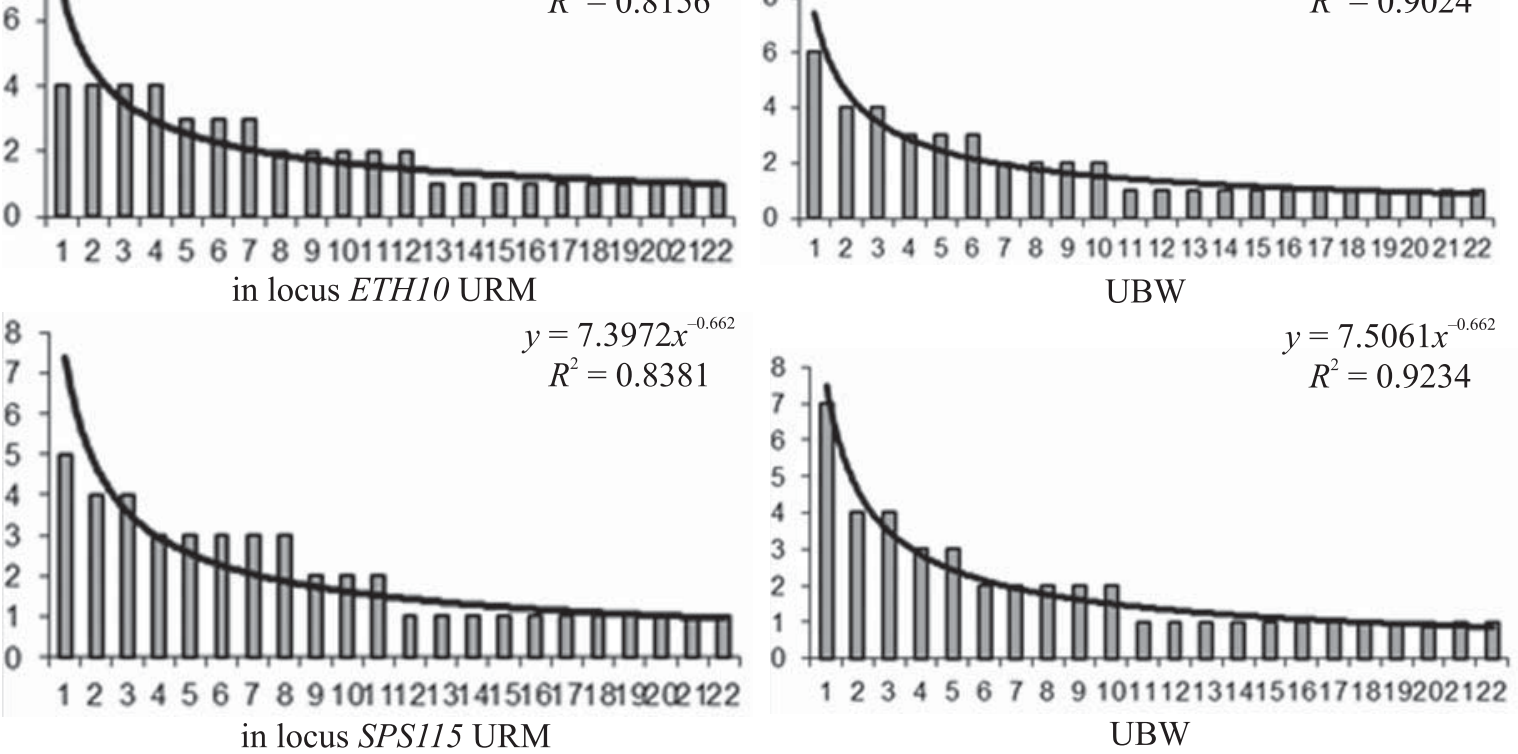

Fig. 2. Character of distribution for genotype frequencies in the investigated cattle breeds in 10 loci of microsatellite DNA, where $y$ - approximating model (selected exponential function) and its adequacy level, $R^{2}$ - determination coefficient 


\section{GENETIC VARIATION DETERMINATION AND INTERBREED DIFFERENTIATION}

tained data allow for the assumption that by the majority of loci both URM and UBW demonstrate high similarity in the distribution of genotype frequencies. For loci TGLA126, INRA23, TGLA227, ETH10 and SPS115 there was an observed tendency, similar to the general one, i.e. the distribution of frequencies in URM and UBW breeds was practically identical, in locus BM1824 it was very similar, and only for four loci (TGLA122, ETH3, ETH225 and BM2113) the investigated animals demonstrated breed-specific character of the distribution of genotype frequencies in locus TGLA126.

\section{CONCLUSIONS}

Our analysis of the presented data allows the assumption that the investigated breeds (populations) demonstrated high level of identity with a simultaneous reliable level of genetic differentiation. This is confirmed with the observed differences by the character of distribution of frequencies of the found allelic variants (profiles of allelic polymorphism) $(\mathrm{P}<0.001)$ and by the distribution of genotypes, which is proven by the estimates of the approximating model (the model of the exponential function) and the degree of its adequacy and determination coefficient.

High level of similarity between the investigated breeds, determined by the results of estimating «potential genotype diversity», obtained on the basis of the rarefaction-procedure, allows stating that by the prevailing majority of loci the animals of both breeds demonstrate high similarity regarding the distribution of genotype frequencies. For both breeds, the character of variability in the investigated microsatellite loci for both the ratio of observed alleles and the character of their distribution corresponds to the stepwise mutation model (SMM).

The results of estimating the indices of allelic (the highest number of found alleles, the number and distribution of breed-specific alleles) and genotypic variability (the number of found rare and breed-specific genotypes), confirmed by nonparametric methods (rarefaction-method and the method of A. Chao) demonstrate high level of genetic differentiation of the investigated breeds.

\section{Визначення генетичної варіативності \\ та міжпородна диференціація двох українських молочних порід великої рогатої худоби за мікросателітними локусами ДНК}

А. В. Шельов ${ }^{1}$, К. В. Копилов ${ }^{1}$, С. С. Крамаренко ${ }^{2}$, О. С. Крамаренко ${ }^{2}$ e-mail: shelyov@gmail.com

${ }^{1}$ Інститут розведення і генетики тварин НААН, Вул. Погребняка 1, с. Чубинське, Київська область, Україна, 08321

${ }^{2}$ Миколаївський національний аграрний університет, Вул. Георгія Гонгадзе 9, м. Миколаїв, Україна, 54020

Мета. Метою нашої роботи було дослідження міжпородної диференціації українських червоно- та чорнорябої порід молочної худоби за результатами аналізу алельного й генотипового поліморфізму мікросателітів ДНК. Методи. Генотипування 88 зразків ДНК двох найчисельніших в Україні молочних порід великої рогатої худоби - української червоно-рябої молочної та української чорно-рябої молочної - проводили за 10 локусами, рекомендованими Міжнародним товариством 3 генетики тварин (ISAG). Було здійснено аналіз алельного та генотипового поліморфізму із застосуванням параметричних та непараметричних методів. Результати. Вперше в Україні викладено результати аналізу алельного та генотипового поліморфізму популяцій українських червоно- та чорно-рябої молочної худоби за використання 10 мікросателітних локусів ДНК. Показано, що мікросателіти ДНК, як високополіморфні генетичні системи, є надзвичайно інформативними маркерами генетичних процесів, які мають місце в популяціях свійських тварин. Висновки. Досліджені породи демонструють достовірний рівень генетичної диференціації й, одночасно, високий рівень подібності, що, безсумнівно, пояснюється однаковими цілями та методами селекційної роботи з ними.

Ключові слова: велика рогата худоба, ДНК-маркери, мікросателіти, біорізноманіття, популяційна генетика.

Определение генетической вариативности и межпородная дифференциация двух украинских молочных пород крупного рогатого скота по микросателлитным локусам ДНК

А. В. Шелев ${ }^{1}$, К. В. Копылов ${ }^{1}$, С. С. Крамаренко ${ }^{2}$, А. С. Крамаренко ${ }^{2}$ e-mail: shelyov@gmail.com

${ }^{1}$ Институт разведения и генетики животных НААН, Ул. Погребняка, 1, с. Чубинское, Киевская область, Украина, 08321

${ }^{2}$ Николаевский национальный аграрный университет, Ул. Георгия Гонгадзе, 9, г. Николаев, Украина, 54020

Цель. Целью нашей работы было исследование межпородной дифференциации украинских красно- и черно-пестрой пород молочного скота по результатам анализа аллельного и генотипического полиморфизма микросателлитов ДНК. Методы. Было использовано 10 локусов, рекомендованных Международным обществом по генетике животных (ISAG), для анализа 


\section{SHELYOV et al.}

88 образцов ДНК двух наиболее многочисленных в Украине молочных пород крупного рогатого скота украинской красно-пестрой молочной и украинской черно-пестрой молочной. Был проведен анализ аллельного и генотипического полиморфизма с применением параметрических и непараметрических методов. Результаты. В работе изложены результаты анализа аллельного и генотипического полиморфизма популяций украинского красно- и черно-пестрого молочного скота с использованием 10 микросателлитных локусов ДНК. Показано, что микросателлиты ДНК, как высоко полиморфные мультилокусные генетические системы, являются сверхинформативными маркерами генетических процессов в популяциях домашних животных. Выводы. Исследованные популяции украинских молочных пород крупного рогатого скота показывают достоверный уровень генетической дифференциации и, одновременно, высокий уровень идентичности, что, несомненно, объясняется схожими целями и методами селекционной роботы с ними.

Ключевые слова: крупный рогатый скот, ДНК-маркеры, микросателлиты, биоразнообразие, генетика популяций.

\section{REFERENCES}

1. Agung PP, Saputra F, Septian WA. Study of Genetic Diversity among Simmental Cross Cattle in West Sumatra Based on Microsatellite Markers. Asian-Australas. J. Anim. Sci. 2016;29(2):176-83. doi: 10.5713/ajas.15.0155.

2. Sharma R, Kishore A, Mukesh M, Ahlawat S, Maitra A, Pandey AK, Tantia MS. Genetic diversity and relationship of Indian cattle inferred from microsatellite and mitochondrial DNA markers. BMC Genet. 2015; 16(1):73. doi: 10.1186/s12863-015-0221-0.

3. Brenig B, Schütz E. Recent development of allele frequencies and exclusion probabilities of microsatellites used for parentage control in the German Holstein Friesian cattle population. BMC Genet. 2016;17(1):18. doi: 10.1186/s12863-016-0327-z.

4. Zinov'eva N, Gladyr H. Genetic examination of farm animals: the use of test systems based on microsatellites. Dostizheniya nauki i tehniki APK. 2011; 9:19-20.

5. Tapio I, Värv S, Bennewitz J, Maleviciute J, Fimland E, Grislis Z, Meuwissen THE, Miceikiene I, Olsaker I, Viinalass H, Vilkki J, Kantanen J. Prioritization for conservation of northern European cattle breeds based on analysis of microsatellite data. Conserv. Biol. 2006; 20(6):1768-79. doi:10.1111/j.1523-1739.2006.00488.x.

6. Cosenza M, Reale S, Lupo T, Vitale F, Caracappa S. Allele frequencies of microsatellite loci for genetic characterization of a Sicilian bovine population. Genet. Mol. Res. 2015;14(1): 691-9. doi: 10.4238/2015.January.30.12.

7. Ilie DE, Cean A, Cziszter LT, Gavojdian D, Ivan A, Kusza S. Microsatellite and Mitochondrial DNA Study of Native Eastern European Cattle Populations: The Case of the Romanian Grey. PLoS ONE. 2015; 10(9): e0138736. doi: 10.1371/journal.pone.0138736.

8. Vohra V, Sodhi M, Niranjan SK, Mishra AK, Chopra A, Kumar M, Joshi BK. Characterization of rare migratory cattle and evaluation of its phylogeny using shorttandem-repeat-based markers. J. App. Anim. Res. 2017; 45(1):355-63. doi.org/10.1080/09712119.2016.1194843.

9. Pham LD, Do DN, Binh NT, Van Ba N, Thuy TTT, Hoan TX, Cuong VC, Kadarmideen HN. Assessment of genetic diversity and population structure of Vietnamese indigenous cattle populations by microsatellites. Livestock Sci. 2013;155(1):17-22. doi: 10.1016/j.livsci.2013.04.006.

10. Suh S, Kim Y-S, Cho C-Y, Byun M-J, Choi S-B, Ko Y-G, Lee $\mathrm{CW}$, Jung K-S, Bae KH, Kim J-H. Assessment of genetic diversity, relationships and structure among Korean native cattle breeds using microsatellite markers. Asian-Australas. J. Anim. Sci. 2014;27(11):1548-53. doi: 10.5713/ajas. 2014.14435.

11. Setyawan AD, Lymbery AJ. Genetic diversity of five Indonesian native cattle breeds at microsatellite loci. Asian J. Anim. Sci. 2015;9(2):57-64. doi 10.3923/ajas.2015.57.64.

12. Weir B. Genetic Data Analysis. Moscow: Mir. 1995;400 p.

13. Peakall $R$, Smouse P. GenAIEx 6.5: genetic analysis in Excel. Population genetic software for teaching and research - an update. Bioinformatics. 2012;28(19):25379. doi: 10.1093/bioinformatics/bts460.

14. Piry S, Luikart G, Cornuet J. BOTTLENECK: a computer program for detecting recent reductions in the effective population size using allele frequency data. J. Heredity. 1999;90(4):502-3.

15. Yeh F, Yang R, Boyle T. PopGene. Microsoft Windows based freeware for population genetic analysis: Quick User Guide. University of Alberta, 1999;27 p.

16. Peel D, Ovenden J, Peel S. NeEstimator: Software for estimating effective population size. Version 1.3. Queensland Government, Department of Primary Industries and Fisheries, Queensland, Australia. 2004.

17. Ewens $W$. The sampling theory of selectively neutral alleles. Theor. Popul. Biol. 1972;3(1):87-112. doi: 10.1016/00405809(72)90035-4.

18. Kimura M, Crow J. The number of alleles that can be maintained in a finite population. Genetics. 1964; 49(4):725-38. PMID: 14156929.

19. Ohta T, Kimura M. A model of mutation appropriate to estimate the number of electrophoretically detectable alleles in a finite population. Genet. Res. 1973;22(2):2014. doi: 10.1017/S0016672300012994.

20. Kimura M, Ohta T. Distribution of allelic frequencies in a finite population under stepwise production of neutral alleles. Proc. Natl. Acad. Sci. USA. 1975;72(7):2761-4.

21. Kimura M, Ohta T. Stepwise mutation model and distribution of allelic frequencies in a finite population. Proc. Natl. Acad. Sci. USA. 1978;75(6):2868-72. PMID: 275857.

22. Chao A. Nonparametric estimation of the number of classes in a population. Scandinav. J. Statist. 1984;11(4): 265-70. http://www.jstor.org/stable/4615964. 